\title{
A matter of record
}

The thing about education is that it relies first and foremost on being able to retain information, but it is the knack of being able to do so that provides the biggest challenge says Stephen Hancocks.

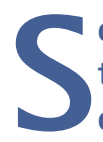
omeone once pointed out to me that nomadic people are very often illiterate for one very good reason. I supposed that it was because they spent the majority time hunting animals, gathering food or generally surviving. No. I guessed again. Was it because they were constantly moving and so never had the opportunity to sit and learn to read? I was told I was getting closer.

The plain fact of the matter is that if you are nomadic you are, probably, walking around. As a consequence you want to carry as little with you as possible. It's tiring and it's literally and metaphorically a burden. Now, think about writing something down or recording it in any manner you can imagine and then ask yourself what you have to do with it next. The answer - carry it. So in essence, as soon as you write something in, say, a book, it becomes so precious that you have to keep it with you and that becomes a burden. Learn it instead and it releases you.

Ok, ok, I hear what you're saying, the majority of us are not nomadic and claiming that we are not only cuts no ice at all with teachers, examiners and granters of certificates but also makes us fairly useless as dentists in big cities, small country towns or even rural backwaters.

'Where's the dentist?'

'Not sure. Wandering about here somewhere.'

Doesn't quite work, does it?

The consequence for we grounded folk is that from fairly near the beginning of our educational lives we have had to record things, 'put them down' in some form or another in order to help us remember by referring. The next fundamental requirement is that the recording has to be in some configuration that is at least

\section{"....what price access now to documents and typescripts lovingly created in WordPerfect?"}

semi-permanent. So chalk on a blackboard is an early and reasonably immediately obvious case of some failure in the keeping for a long time stakes. Reference to the handwritten menu board outside a pub announcing 'sop of the day - mush' with blurry white patches in the middle of 'sop' and after 'mush' might indicate vandalism to the original 'soup of the day - mushroom' but by then the passing trade has shrugged and gone elsewhere.

More permanent materials such as stone might have their place but then again, chipping your lecture notes into large slabs of Portland or marble takes time, dedication and at least a hardy mule cart if not a $4 \times 4$ to get your daily scribings back home. Although my erudite guide to nomadic illiteracy also pointed out that the Chinese had invented the photocopier thousands of years before Xerox by having stone tables with various types of wisdom chiselled on them from which a brass-rubbing-type copy on parchment provided an accurate and portable version of the original. Some people are too smart for their own good, don't you think? Besides, he'd have had to read that in a book wouldn't he?

Moving on. Ink. Ink is the next vehicle for communication that we come across. The quill and ink pot has made many a schoolboy's fingers black with its leaky persistence and even our modern ballpoints are not without their occasional ability to explode in a breast pocket, staining a white shirt with an assassination type splat of dramatic colour, causing onlookers to faint in misapprehension.

But tirelessly we note down ream after ream of lined A4 paper on lectures, from books, in practical classes, at the laboratory bench and keep them carefully in ring binders, clip books, folders, document wallets, cases, all types of secure devices to hold the information safe against our needing it again. Not that such methods are always foolproof. How many of us, returning some months later to typed sheets neatly filed in plastic wallets have found the top sheet chemically stuck and effectively embossed on the inside of the front face? Remember that sickening tearing sound as the paper comes away from the file leaving bits of black type-face characters all over the floor, or your clothes, and shredding your knowledge at the same time?

For a while the brave new world of electronics held out the promise of ease, the assurance of permanence and the convenience of tiny weight. Recorded or dictated tapes removed, at the press of a button or two, all that angst about jotting stuff down. Then disaster stuck. Pioneering magnetics got wiped; they stopped making the machines to play reel-to-reel reels; cassettes replaced cartridges; mice eat tape.

Well computers then. Surely now we have the equivalent of the student's nirvana? Easily typed, spell checked, grammar corrected even. Stored on hard drives, or floppies? Hard drives - crash. Does your new laptop have a floppy slot? 'A' drives? How drearily 1990s my dear. And what price access now to documents and typescripts lovingly created in WordPerfect or another last century computer program?

Perhaps, when all is said and done, that old nomadic scheme of things isn't such a bad idea after all. If you can't remember it then it probably isn't that important anyway and if it is important either someone else will recall it or your tribe is just about to become extinct. Walk on. $\mathrm{H}$

DOI: 10.1038/bdj.2007.782 